March 2003 • NREL/CP-560-33620

\title{
Solar Radiation Modeling and Measurements for Renewable Energy Applications: Data and Model Quality
}

\section{Preprint}

D.R. Myers

To be presented at the International Expert Conference on Mathematical Modeling of Solar Radiation and Daylight-Challenges for the $21^{\text {st }}$ Century Edinburgh, Scotland September 15-16, 2003
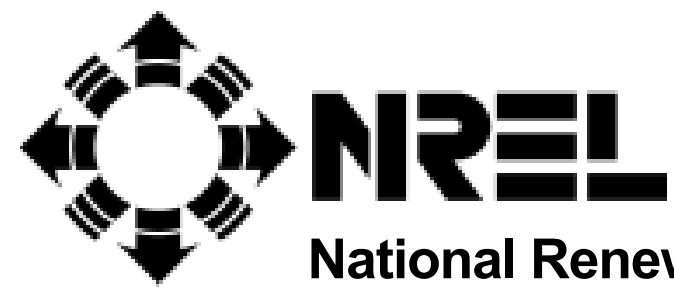

National Renewable Energy Laboratory

1617 Cole Boulevard Golden, Colorado 80401-3393

NREL is a U.S. Department of Energy Laboratory Operated by Midwest Research Institute $\bullet$ Battelle $\bullet$ Bechtel 


\section{NOTICE}

The submitted manuscript has been offered by an employee of the Midwest Research Institute (MRI), a contractor of the US Government under Contract No. DE-AC36-99G010337. Accordingly, the US Government and MRI retain a nonexclusive royalty-free license to publish or reproduce the published form of this contribution, or allow others to do so, for US Government purposes.

This report was prepared as an account of work sponsored by an agency of the United States government. Neither the United States government nor any agency thereof, nor any of their employees, makes any warranty, express or implied, or assumes any legal liability or responsibility for the accuracy, completeness, or usefulness of any information, apparatus, product, or process disclosed, or represents that its use would not infringe privately owned rights. Reference herein to any specific commercial product, process, or service by trade name, trademark, manufacturer, or otherwise does not necessarily constitute or imply its endorsement, recommendation, or favoring by the United States government or any agency thereof. The views and opinions of authors expressed herein do not necessarily state or reflect those of the United States government or any agency thereof.

Available electronically at http://www.osti.gov/bridge

Available for a processing fee to U.S. Department of Energy and its contractors, in paper, from:

U.S. Department of Energy

Office of Scientific and Technical Information

P.O. Box 62

Oak Ridge, TN 37831-0062

phone: 865.576.8401

fax: 865.576.5728

email: reports@adonis.osti.gov

Available for sale to the public, in paper, from:

U.S. Department of Commerce

National Technical Information Service

5285 Port Royal Road

Springfield, VA 22161

phone: 800.553 .6847

fax: 703.605.6900

email: orders@ntis.fedworld.gov

online ordering: http://www.ntis.gov/ordering.htm

Printed on paper containing at least $50 \%$ wastepaper, including $20 \%$ postconsumer waste 


\title{
Solar Radiation Modeling and Measurements for Renewable Energy Applications: Data and Model Quality
}

\author{
Daryl R. Myers \\ National Renewable Energy Laboratory \\ 1617 Cole Blvd Golden CO 80401
}

\begin{abstract}
Measurement and modeling of broadband and spectral terrestrial solar radiation is important for the evaluation and deployment of solar renewable energy systems. We discuss recent developments in the calibration of broadband solar radiometric instrumentation and improving broadband solar radiation measurement accuracy. An improved diffuse sky reference and radiometer calibration and characterization software and for outdoor pyranometer calibrations is outlined. Several broadband solar radiation model approaches, including some developed at the National Renewable Energy Laboratory, for estimating direct beam, total hemispherical and diffuse sky radiation are briefly reviewed. The latter include the Bird clear sky model for global, direct beam, and diffuse terrestrial solar radiation; the Direct Insolation Simulation Code (DISC) for estimating direct beam radiation from global measurements; and the METSTAT (Meteorological and Statistical) and Climatological Solar Radiation (CSR) models that estimate solar radiation from meteorological data. We conclude that currently the best model uncertainties are representative of the uncertainty in measured data.
\end{abstract}

\subsection{Introduction}

Just as the fossil fuel based energy industry relies on exploration and proven reserves for discovery and economic support of energy markets, the renewable energy sector depends upon the assessment of resources for planning and selling their energy production technology. For solar-based renewable energy technologies such as solar thermal or photovoltaic conversion systems, the basic resource or fuel available is solar radiation. Colle et al.,[1] have shown that uncertainty in life cycle savings for solar thermal and photovoltaic (PV) systems are linearly correlated with uncertainty in solar resource data.

Assessment of the solar resource for these technologies is based upon measured data, where available. However, the sparse distribution in space, and particularly over time, of measured solar data leads to the use of modeled solar radiation as the basis for many engineering and economic decisions. Measured and modeled solar radiation have attendant uncertainties. Most solar radiation models rely on measured data for their development or validation, and often the uncertainty or accuracy of that measured data is unknown. Below, we identify the major components of uncertainty in measured solar radiation data and characterize solar radiation modeling in general with respect to uncertainties reported in the literature.

\subsection{Solar Instrumentation Calibrations and Measurements}

Terrestrial solar radiation measurements are based on pyranometers that respond to radiation within a 2-pi steradian (hemispherical) field of view, and/or pyrheliometers, narrow field of view instruments $\left(5.8^{\circ}\right.$ to $\left.5.0^{\circ}\right)$ that measure the nearly collimated (i.e., parallel rays) radiation from the $0.5^{\circ}$ diameter solar disk and a small part of the sky. Hemispherical sky radiation can be measured by shading a pyranometer with a disk located to subtend the same angular field of view as a pyrheliometer. 
The total hemispherical (sky + solar disk) radiation, $\mathrm{G}$, on a horizontal surface is the sum of the direct beam, B, projected on the surface (modified by the cosine of the incidence angle of the beam, I, and sky radiation, $\mathrm{D}$, from the dome of the sky excluding the sun. The expression for this relation is $G=B \operatorname{Cos}(i)+D$, where $i$ is the angle between the solar disk and the normal to the horizontal surface. Examples of the instrumentation are shown in figure 1.

The theoretical relationship shows that measurement of any two of the radiation quantities permits computation of the third. This component equation is the basis of the outdoor calibration of radiometers. Namely, many pyranometers can be calibrated simultaneously using direct beam and sky diffuse measurements with highly specialized and well-characterized reference pyrheliometers and pyranometers.

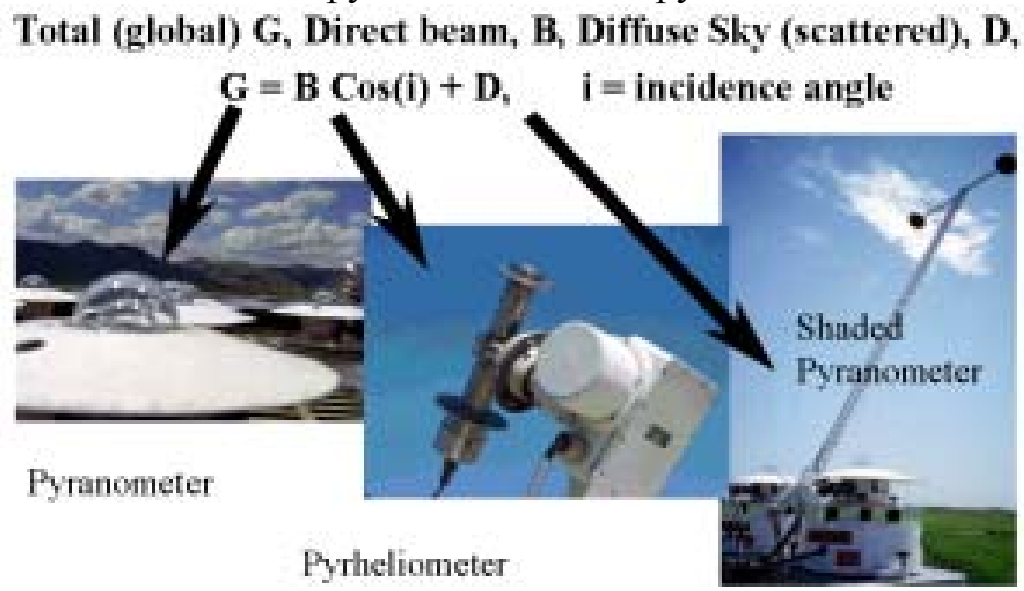

Figure 1. Instruments for measuring solar radiation components.

The solar radiation measurement scale is based upon the World Radiometric Reference (WRR) maintained by the World Meteorological Organization (WMO) at the Physical Meteorological Observatory, Davos (PMOD, Davos), Switzerland[2]. The WRR is established using a group of "absolute cavity" pyrheliometers (ACP). These pyrheliometers are "absolute" since their calibrations are based on measurement of electrical current and voltage to produce power equivalent to heating of a "cavity" trap detector that is equivalent to the power absorbed when trapping solar radiation. These pyrheliometers are characterized for the physical properties listed in table 1[3] .

Table 1. Uncertainties in Characterization of Absolute Cavity Pyrheliometers.

\begin{tabular}{|l|cc|}
\hline Cavity Pyrheliometer Parameter & \multicolumn{2}{|l|}{$\begin{array}{l}\text { Uncertainty } \\
\text { Parts Per Million (\%) }\end{array}$} \\
\hline Power (Current x Voltage measured) & 200 & $(0.020)$ \\
\hline Aperture Area & 800 & $(0.080)$ \\
\hline Radiative Loss (escaping cavity) & 200 & $(0.020)$ \\
\hline $\begin{array}{l}\text { Nonequivalence (electrical vs. solar heating } \\
\text { paths) }\end{array}$ & $1500(0.150)$ \\
\hline Aperture Heating & 180 & $(0.018)$ \\
\hline Stray Light & 200 & $(0.020)$ \\
\hline Lead Resistance Heating & 50 & $(0.005)$ \\
\hline Root Sum Square Total x 2 & $\mathbf{3 4 8 9}$ & $\mathbf{( 0 . 3 4 9 )}$ \\
\hline
\end{tabular}


As shown in table 1 , the overall uncertainty in the WRR scale is $0.35 \%$. Working reference cavity pyrheliometers used by solar radiation calibration laboratories are compared outdoors with pyrheliometers embodying the WRR, resulting in an additional $0.1 \%$ transfer uncertainty. Working reference cavity radiometers are used as the reference against which to calibrate both pyranometers and pyrheliometers used in the field. Thus the uncertainty in the reference irradiance direct beam component measured with a working reference ACP is $0.45 \%$, or about $5 \mathrm{~W} / \mathrm{m}^{2}$ at $1000 \mathrm{~W} / \mathrm{m}^{2}$ direct irradiance.

The sky radiation component during an outdoor calibration requires characterizing the responsivity of a reference pyranometer for the shaded, measurement[4]. The classical procedure for determining this responsivity is the shade/unshade technique. The pyranometer under test is periodically shaded and unshaded with a disk subtending the same solid angle as the field of view of the ACP. Assuming the pyranometer detector has a perfect Lambertian response (directly proportional to the cosine of the incidence angle of the radiation), the difference between the shaded and unshaded signals from the test pyranometer is proportional to the vertical component of the direct beam radiation measured with the ACP. Procedures for acquiring shade/unshade calibration data are described in the American Society for Testing and Materials Standard E-913[4] . Figure 2 is a typical measurement sequence for such a calibration. Time period $\mathrm{A}$ is a 30 -minute stabilization period. Period B is 20 to 30 time constants (1/e, or $63 \%$ of final steady-state values) for the instrument response.

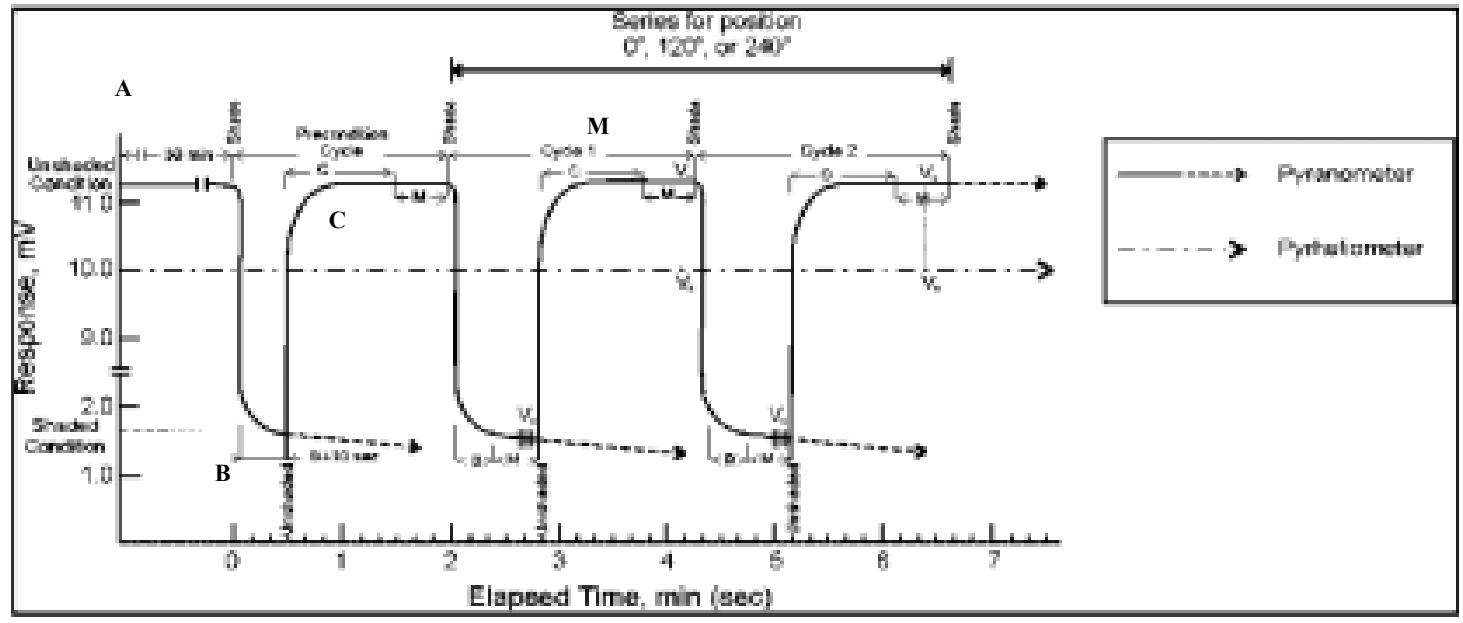

Figure 2. Classic schematic timing diagram for shade/unshade pyranometer calibration sequence.

Period $\mathrm{C}$ is 60 time constants for the instrument response. During period $\mathrm{M}$ at least three readings of instrument shaded or unshaded response and the direct-beam irradiance, are recorded. The mean incidence (zenith) angle and ACP data during the measurement periods $\mathrm{M}$ are used in computing the $\mathrm{B} x \cos (\mathrm{i})$ terms.

During such a characterization, additional sources of uncertainty may be present.

Thermopile-based pyranometers rely on the temperature difference between junctions of dissimilar metals in contact with a surface that absorbs solar radiation ("hot" junctions) and reference, or "cold" junctions, that do not receive any solar radiation. In Figure 3, the top unit is an example of an "all-black" sensor pyranometer. The bottom unit has thermopile hot junctions in contact with a black absorbing surface and the 


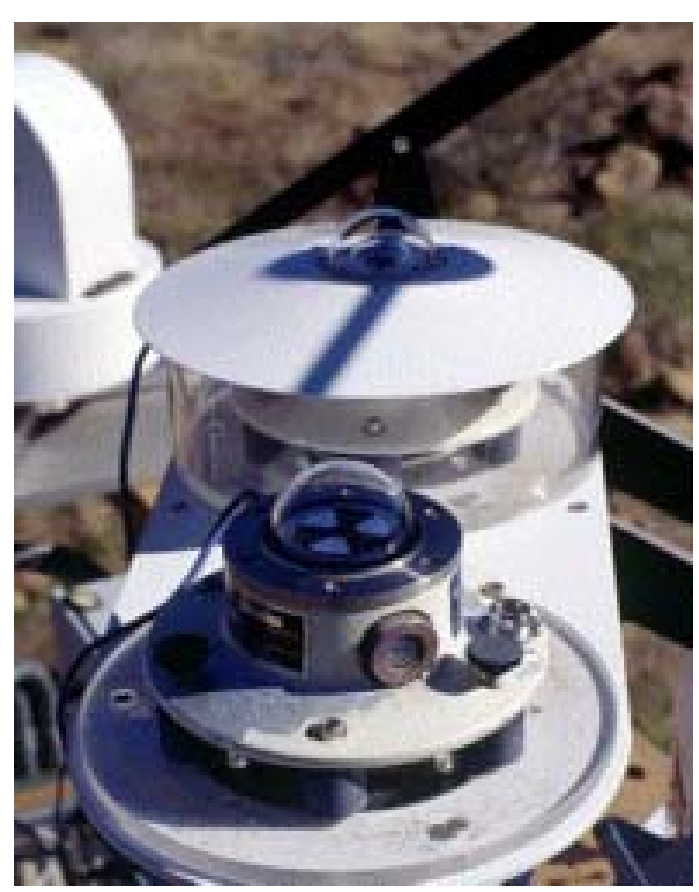

Figure. 3. All-black (top unit) and blackand-white thermopile pyranometers under tracking shading disks. reference cold junctions under a white surface absorbing little shortwave solar radiation, an example of a "black-and-white" sensor unit.

Pyranometers with all-black receivers are rarely in thermal equilibrium outdoors. Thermal energy is exchanged among the absorbing sensor, dome, and sky. These exchanges result in a net negative thermal offset, $\mathrm{W}_{\text {off, }}$ in the thermopile voltage signal[5]. Black-and-white pyranometer thermal offsets are smaller as all junctions see the same thermal environment. Figure 4 is a plot of allblack (PSP) detector (lower line) and a blackand-white detector (upper line) clear-sky diffuse irradiance at NREL. The $20 \mathrm{~W} / \mathrm{m}^{2}$ difference is approximately constant for clearsky conditions throughout the year, and it is the value of $\mathrm{W}_{\text {off }}$ in the following section on uncertainty. The $\mathrm{W}_{\text {off }}$ for the black-and-white units is about $2 \mathrm{~W} / \mathrm{m}^{2}$. We note that the thermal offset is site dependent, depending upon the thermal environment for the climate where the radiometer is deployed.

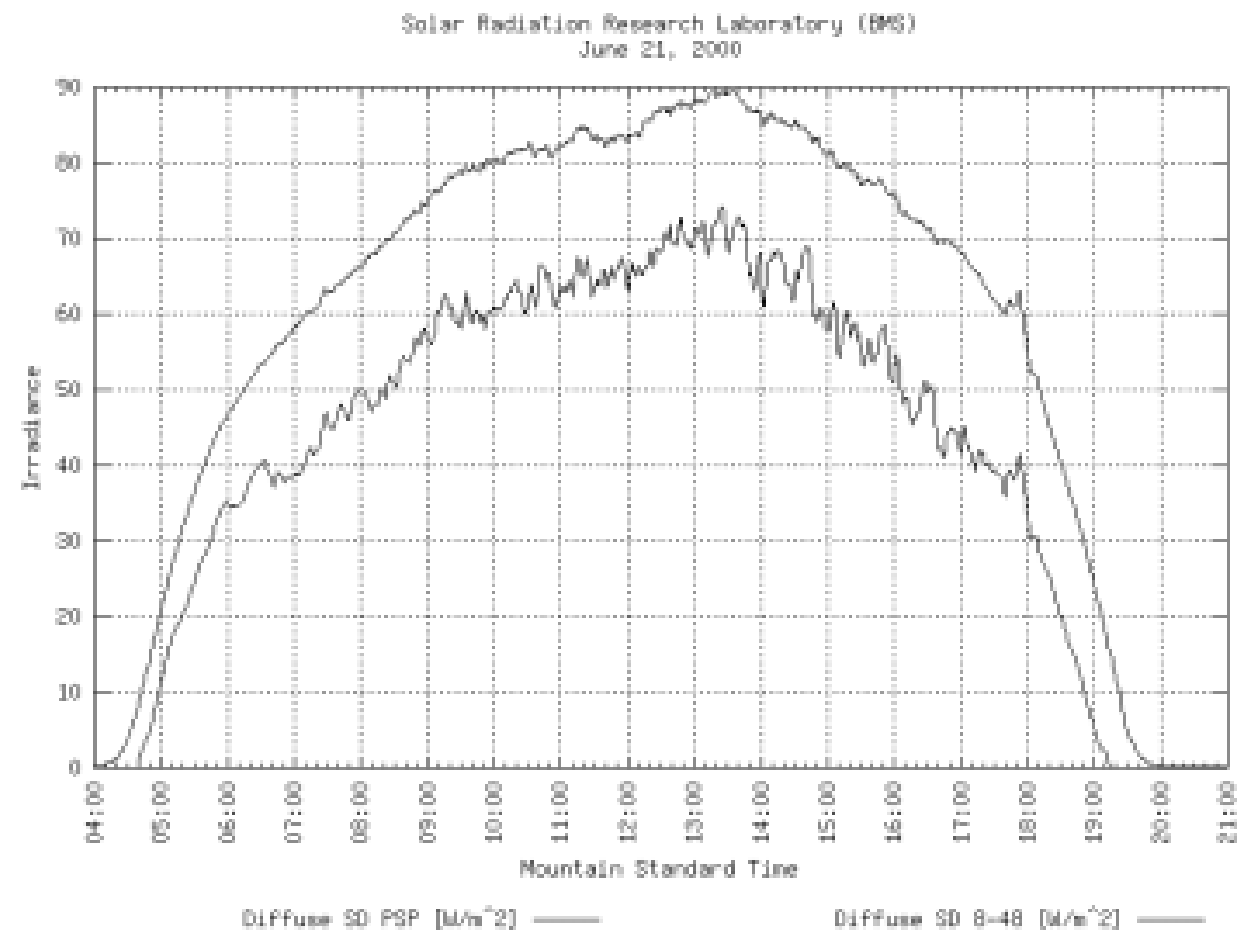

Figure 4. Black-and-White (top line) and all-black sensor clear sky diffuse irradiance demonstrating 20 $\mathrm{W} / \mathrm{m}^{2}$ thermal offset in all-black pyranometer on a clear day. The all-black unit has a faster time response. 
Figure 5 shows the distribution of night-time themal offsets (an indicator of the approximate magnitude of thermal offsets) for all-black sensors in a continental climate (at NREL, Golden Co) and a desert environment (12 station network in Saudi Arabia) compared with night-time offsets for a black-and-white sensor.

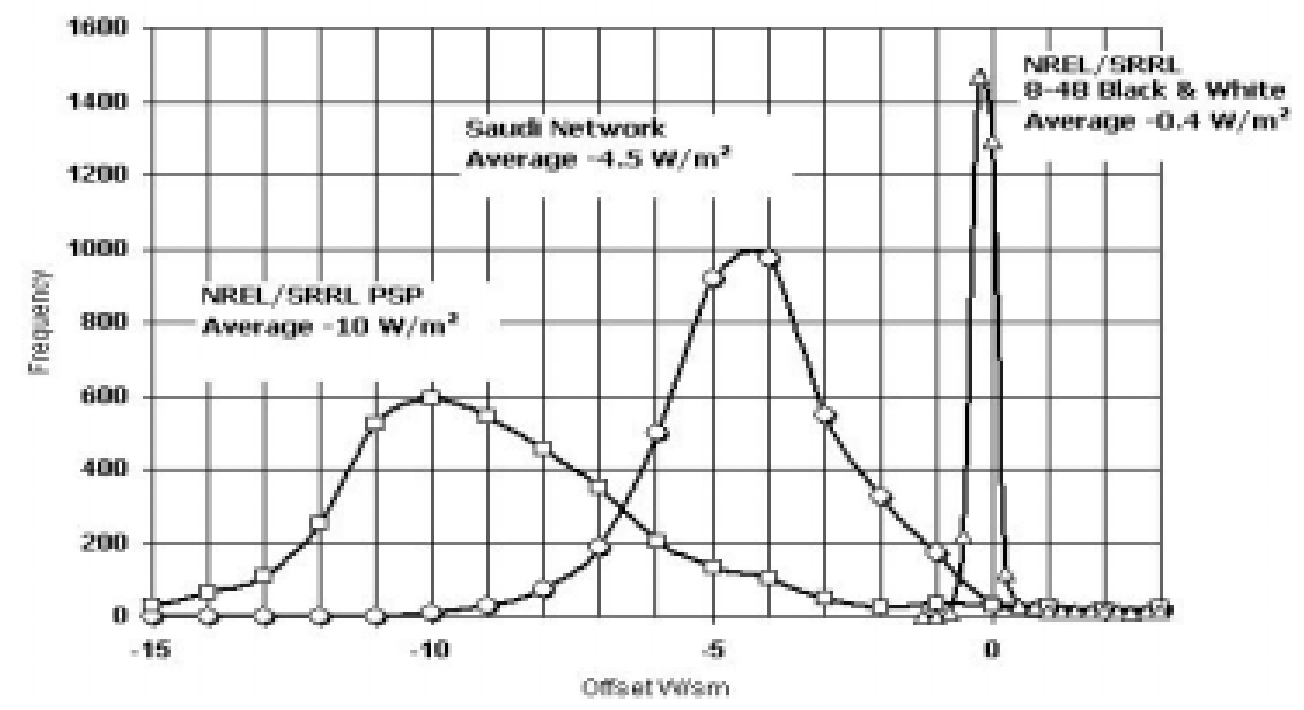

Figure 5. Distribution of annual average night-time thermal zero-offsets for all-black sensors in a continental (NREL) and a desert (12 station Saudi Arabian Network) climate. Black-and-white offset distribution for comparison.

Using an all-black sensor pyranometer in conjunction with an ACP to compute a reference hemispherical irradiance will lead to a low reference irradiance, and hence a higher responsivity (output per irradiance unit) for the calibrated instruments. Since calibration factors for computing irradiance are the recipricol of responsivity (irradiance unit per output unit), most radiometers calibrated in recent years can be expected to have underestimated global irradiance on the order of $5 \mathrm{~W} / \mathrm{m}^{2}$ to $20 \mathrm{~W} / \mathrm{m}^{2}$ on clear days, (often considered the easiest to model).

\subsection{Solar Radiometer Response Characterization}

Using the high accuracy ACP and well characterized reference pyranometer to calibrate pyranometers for measuring hemispherical radiation, we find that the response of each individual pyranometer is not flat, nor even representative of a make or model of radiometer[6] . Figure 6 displays responsivities as a function of incidence angle (left) and time of day (right). From such data, usually a single responsivity, or calibration factor (say, at $45^{\circ}$ incident angle) is selected for use with a data logger or for computing the measured irradiance. Thus through part of the day, like a stopped clock which is correct twice a day, the radiometer underestimates or overestimates the radiation when the single calibration factor is applied. Note the range of responsivities for this instrument is $+/-3.5$ $\%$ for incidence angles between $30^{\circ}$ and $70^{\circ}$, with respect to $45^{\circ}$. This corresponds to $-35 \mathrm{~W} / \mathrm{m}^{2}$ error at midday with respect to $1000 \mathrm{~W} / \mathrm{m}^{2}$ clear day signal) and $+15 \mathrm{~W} / \mathrm{m}^{2}$ 


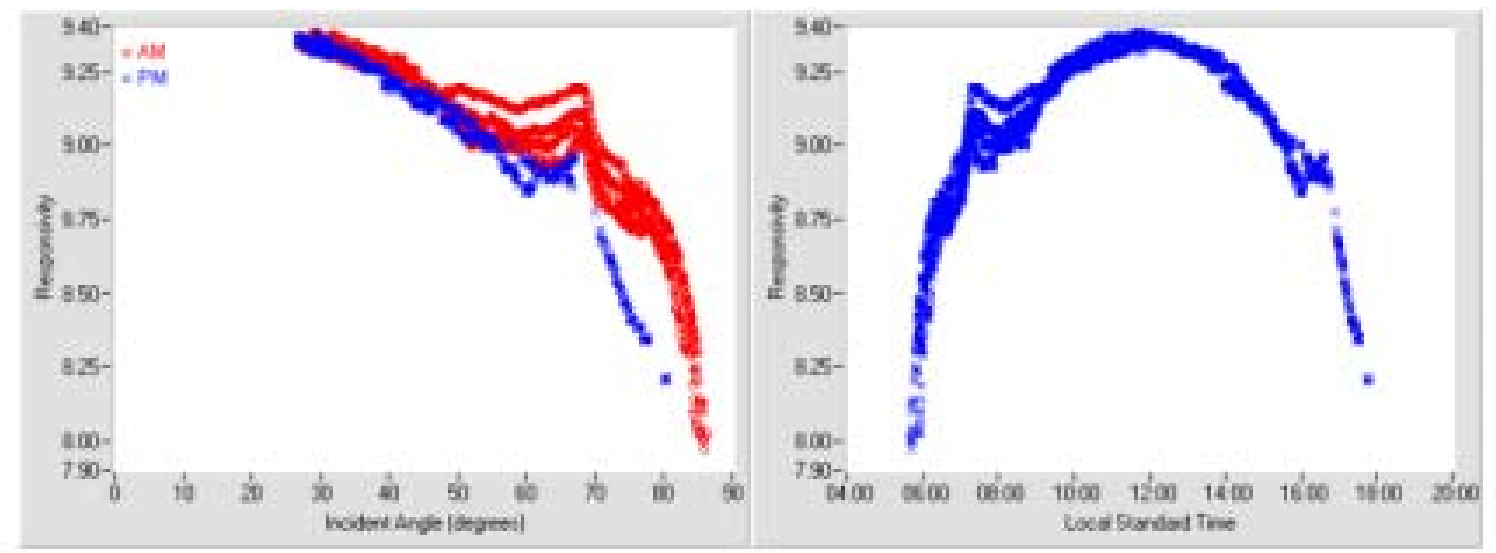

Figure 6. Pyranometer cosine response curve as function of incidence angle and time of day. Morning data is "top" leg, afternoon data the "bottom" leg in left panel.

error in the morning or afternoon, with respect to a reasonable irradiance of $400 \mathrm{~W} / \mathrm{m}^{2}$ at those times.

Pyrheliometers measuring the direct beam also show instrument responsivities, varying by typically $1.5 \%$ to $2.0 \%$, when mapped out during comparison with an ACP. The responsivities vary with metorological and possibly atmospheric conditions, even on clear days, as shown in figure 7 . For a $1000 \mathrm{~W} / \mathrm{m}^{2}$ signal this amounts to irradiance errors of 15 to $20 \mathrm{~W} / \mathrm{m}^{2}$ when a single calibration factor is applied to compute the direct radiation.

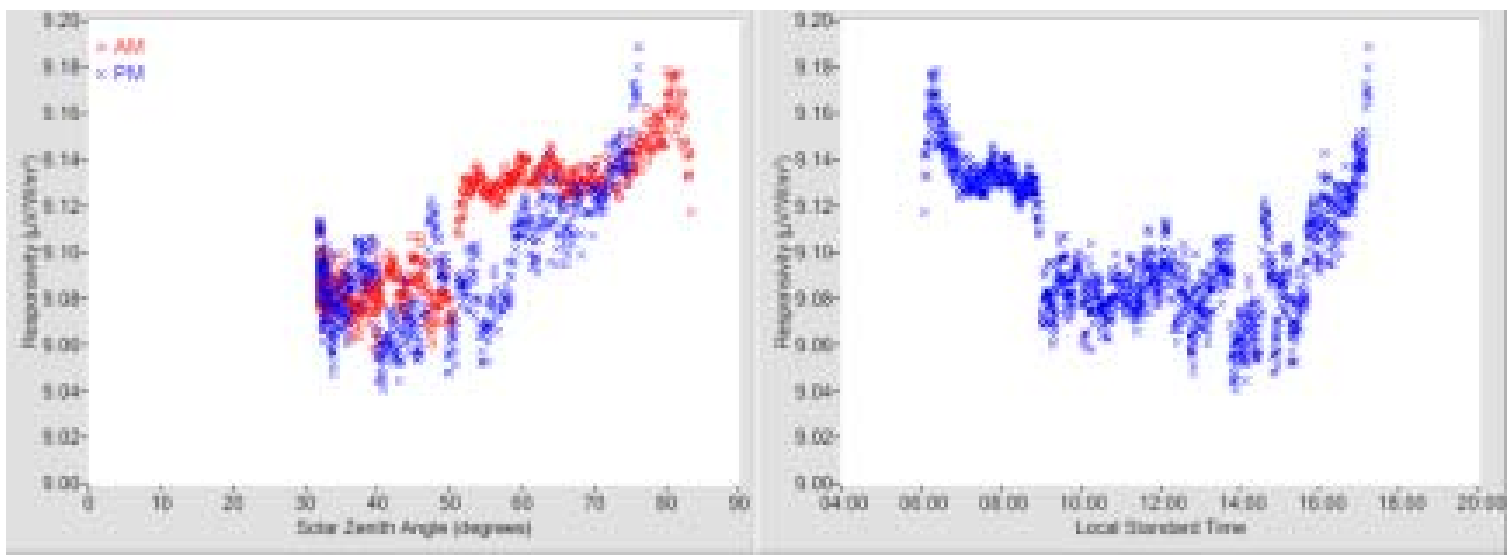

Figure 7. Variation in responsivity of normal incidence pyrheliometer calibrated by direct comparison with absolute cavity radiometer. Variations are correlated with temperature, aerosol optical depth, wind speed and wind direction.

If pyranometer data and pyrheliometer data are calibrated against an appropriate reference irradiance (i.e., black-and-white reference diffuse radiometer and ACP), and responsivity correction curves are applied, the lowest uncertainty that can be approached in any of the measured data is on the order of $1 \%$ of full scale $\left(=1000 \mathrm{~W} / \mathrm{m}^{2}\right)$, of $+/-10$ $\mathrm{W} / \mathrm{m}^{2}$, as can be seen in the $0.5 \%$ spread of responsivity defining the characteristic curves in figures 6 and 7, in addition to the $0.5 \%$ "base uncertainty" in the reference irradiance. 
Table 2 shows uncertainty components for each individual responsivity calculated, and typical uncertainty for measured data derived from using a single calibration "constant" [6] .

Table 2. Uncertainty components and combined uncertainty for solar radiometer responsivities, and typical uncertainty limits for radiometric data obtained by using a single calibration "constant".

\begin{tabular}{|c|c|c|}
\hline Sensor & Pyranometer & Pyrheliometer \\
\hline Uncertainty & $=$ Mean of base uncertainties $(\%)$ & $\mathrm{U}_{\text {std }}=$ Standard deviation, base uncertainties \\
\hline \multirow[t]{7}{*}{ Components } & $\mathrm{U}_{\text {std }} \quad=$ Standard deviation, base & $\mathrm{RS}_{\max }=$ Highest responsivity (all data) \\
\hline & $\mathrm{RS}_{\max }=$ Highest responsivity (all data) & $\mathrm{RS}_{\min }=$ Lowest responsivity (all data) \\
\hline & $\mathrm{RS}_{\min }=$ Lowest responsivity (all data) & $\mathrm{U}_{\mathrm{avg}} \quad=$ Mean of base uncertainties (\%) \\
\hline & = Mean responsivity @ 45 & = Mean responsivity @ 45 \\
\hline & $=\left[\mathrm{U}_{\mathrm{avg}}{ }^{2}+\left(2 \cdot \mathrm{U}_{\mathrm{avg}}\right)^{2}\right]^{1 / 2}$ & Range $=100 \cdot\left(\mathrm{RS}_{\max }-\mathrm{RS}_{\min }\right) / \mathrm{RS}$ \\
\hline & $=100 \cdot\left(\mathrm{RS}_{\max }-\mathrm{RS}\right) / \mathrm{RS}$ & \\
\hline & $\mathrm{E}_{-} \quad=100 \cdot\left(\mathrm{RS}-\mathrm{RS}_{\min }\right) / \mathrm{RS}$ & \\
\hline Combined & $\mathrm{U}_{95}+\quad=+\left(\mathrm{U}_{\mathrm{rad}}+\mathrm{E}_{+}\right)$ & \multirow[t]{2}{*}{$\mathrm{U}_{95}=\left[\mathrm{U}_{\mathrm{avg}}{ }^{2}+\left(2 \cdot \mathrm{U}_{\mathrm{std}}\right)^{2}+(\text { Range } / 2)^{2}\right]^{1 / 2}$} \\
\hline Uncertainty & $=-\left(\mathrm{U}_{\mathrm{rad}}+\mathrm{E}_{-}\right)$ & \\
\hline $\begin{array}{l}\text { Typical } \\
\text { Values } \\
\left(30^{\circ}<\mathrm{Z}<70^{\circ}\right)\end{array}$ & $\begin{array}{c}+2.5 \%-10.0 \% \\
\text { of FULL SCALE }=1000 \mathrm{~W} / \mathrm{m}^{2} \\
=>+25 \mathrm{~W} / \mathrm{m}^{2} \text { to }-100 \mathrm{~W} / \mathrm{m}^{2}\end{array}$ & $\begin{array}{c} \pm 2.5 \% \\
\text { of FULL SCALE }=1000 \mathrm{~W} / \mathrm{m} 2 \\
=>+25 \mathrm{~W} / \mathrm{m}^{2} \text { to }-25 \mathrm{~W} / \mathrm{m}^{2}\end{array}$ \\
\hline
\end{tabular}

Errors between $+25 \mathrm{~W} / \mathrm{m}^{2}$ to $-100 \mathrm{~W} / \mathrm{m}^{2}$ are possible in pyranometer data, and $+/$ $25 \mathrm{~W} / \mathrm{m}^{2}$ errors in pyrheliometer data can occur under clear sky conditions. Under near isotropic conditions, or partly cloudy conditions, the errors will be less. These instrumental errors are important only if modeling instantaneous, subhourly, or hourly data, or daily profiles. Analysis of annual totals of corrected and uncorrected data has shown differences of less than $0.1 \%$ in the result[7].

This exercise in radiometric metrology and uncertainty analysis shows that part of the root-mean-square or bias errors between hemispherical model validation data sets and models is contibuted from the instrumentation, and are not all due to model difficiencies.

\subsection{Radiation Models for Solar Technology Applications}

In the light of the above revelations concerning measurement data, we here describe the needs of the solar technology community, and model approaches to meet those needs.

\subsection{Technology Needs}

Design of solar thermal and PV conversion systems require several types of data. The main categories of data often requested by users are shown in table 3 . As mentioned in the introduction, uncertainty in economic analysis of solar energy systems is directly proportional to the uncertainty in solar resource data. Colle et al.[1] show that the relative uncertainty in life cycle savings is especially sensitive in cases of high capital cost or low auxiliary energy cost. Many technologies depend on resources on a tilted surface. However, tilt conversion models (such as that of Perez et al.[33]) generally begin with resources on a horizontal surface, the most commonly measured and modeled parameter. 
Table 3. Data formats requested by solar energy system designers and planners.

\begin{tabular}{|c|c|c|}
\hline Type of Data & $\begin{array}{c}\text { Time } \\
\text { Resolution } \\
\end{array}$ & Application \\
\hline Hemispherical, vertical surface, cardinal dir. & Seasonal/Daily & Glazing energy balance (energy or power) \\
\hline Illuminance, vertical surfaces, cardinal dir. & Seasonal/Daily & Daylighting \\
\hline Hemispherical tilt & Monthly/Annual & Fixed Flat Plate \\
\hline Hemispherical tracking & Monthly/Annual & Tracking Flat Plate \\
\hline Direct normal & Monthly/Annual & Focusing/concentrating systems \\
\hline Sunshape (disk+circumsolar) variation & Varies & Concentrating tracking collector \\
\hline Monthly mean daily total & Monthly/Daily & Sizing and design specification, economics \\
\hline Monthly mean & Monthly & Sizing and design specification, economics \\
\hline Daily profiles & Hourly & System simulation modeling and rating \\
\hline $\begin{array}{c}8760 \text { Hourly data for year hemispherical } \\
\text { and/or direct }\end{array}$ & Hourly & $\begin{array}{c}\text { System simulation, economic analysis } \\
\text { (multiple years for min/max performance) }\end{array}$ \\
\hline 10 to 30 year hourly power & Hourly & $\begin{array}{c}\text { Performance and economics, } \\
\text { system lifetime }\end{array}$ \\
\hline Daily profiles power & Sub Hourly & System responses to clouds, etc. \\
\hline
\end{tabular}

At NREL, efforts to meet the need for hourly data have resulted in the Bird Clear Sky Model[8] and extensions to the METSTAT and CSR models of Maxwell[9, 10] . METSTAT calculates radiation components from METeorological input parameters, using empirical correlations to produce radiation estimates that have, on a monthly basis, STATistical properties (moments, kurtosis) close to those of measured radiation data. To meet the need for monthly mean data, the NREL Climatological Solar Radiation (CSR) model was developed. The CSR uses METSTAT algorithms with monthly mean inputs derived from satellite products to produce estimates of monthly mean radiation on a 40 $\mathrm{km}$ grid. For annual means of direct and hemispherical hourly data, the METSTAT model has mean bias differences ranging from $-15 \%$ to $+15 \%$, with mean of the absolute value of the MBD for 33 sites in the US of $5.2 \%$ for the direct beam and 3.0\% for hemispherical[11] . For the CSR model, mean of absolute value of bias differences between modeled and measured hemispherical data annual mean monthly daily totals for eight stations in Egypt was 1.0\%, and mean random differences were 9.0\%. A summary of other model approaches and current estimates of their accuracy are compared with the uncertainty in measured data in the following sections.

\subsection{Sunshine Fraction and Hemispherical Solar Radiation}

Much solar radiation data is available as a percent of available sunshine, or sunshine duration, or hemispherical data on a horizontal surface. Many models for converting sunshine duration to hemispherical radiation and for converting hemispherical data on a horizontal to tilted surface have been developed. The former rely on the "Angstrom" relation, $\mathrm{H} / \mathrm{Hclear}=\mathrm{a}^{*}(1-\mathrm{a})^{*} \mathrm{~S}$ where $\mathrm{H}$ is hemispherical radiation on a horizontal surface, and Hclear is a clear sky limit for hemispherical radiation, $\mathrm{S}$ is sunshine fraction (of total possible) and a is a site dependent empirical constant. Hclear 
is sometimes replaced with the extraterrestrial radiation on a horizontal surface, Ho, and the relation is written as $\mathrm{H} / \mathrm{Ho}=\mathrm{a}+\mathrm{b}^{*} \mathrm{~S}$. Many papers have been written on these correlations. Gueymard et al.[12] give a detailed review of this approach, and the problems arising from instrumental measures of $\mathrm{S}$ and seasonal and climate variability.

Improved Angstrom type models result in mean bias (MB) and root-mean-square (RMS) differences from mean daily total observed radiation of $-2 \%$ and $6 \%\left(-55 \mathrm{Wh} / \mathrm{m}^{2}\right.$ and $\left.166 \mathrm{Wh} / \mathrm{m}^{2}\right)$, respectively, at $10 \mathrm{MJ}\left(2770 \mathrm{Wh} / \mathrm{m}^{2}\right)$ and $-11 \%$ and $16 \%\left(-397 \mathrm{Wh} / \mathrm{m}^{2}\right.$ and $\left.577 \mathrm{Wh} / \mathrm{m}^{2}\right)$, respectively, at $13 \mathrm{MJ}\left(3610 \mathrm{Wh} / \mathrm{m}^{2}\right)$. Note how these results are about a factor of 2 to 4 larger than typical instrumental uncertainties in table 2 above, for measured hemispherical radiation.

A 1988 International Energy Agency report[13] on the validation of solar radiation models declared "There is little to recommend sunshine based models. Even though the Angstrom equation can be easily tuned to a location's climatic conditions by simple regression, it requires the existence of radiation data in the first place to produce the prediction equation..."

\subsection{Direct Solar Radiation Models}

Direct beam (pyrheliometer) data is sparse because of the added expense of the required solar tracking equipment. The direct beam is also the fundamental starting point for many solar radiation models. Modeling of the direct beam seems to be considered a bit more straightforward than modeling of diffuse or global radiation. However, the same factors complicating the modeling of diffuse or global radiation also affect the direct beam. Absorbing and scattering processes in the atmosphere redistribute energy out of the direct beam into the diffuse, and consequently into the total hemispherical radiation. There are two approaches to modeling direct beam irradiance: models based on physical principals, and models for converting (or extracting) direct beam data from hemispherical data.

Direct beam models based on physical principles apply cataloged absorption and scattering data, spectrally or as parameterized transmittance functions (for ozone, atmospheric gases, water vapor, and molecular or Rayliegh scattering), to the extraterrestrial direct beam spectral radiation.

\subsubsection{Direct Beam from First Principles}

"First principles" models of direct beam are actually spectral models, relying on modification of the extraterrestrial direct beam spectrum by spectral absorption parameters or coefficients. Examples are the so-called "line-by-line" or LBL models[1416] . An example is Fast Atmospheric Signature Code (FASCODE) developed by the Air Force Geophysical Laboratory (AFGL)[13]. These models are for narrow bandwidth regions and require significant computational resources and storage space. LBL models access databases, such as HITRAN[17] consisting of quantum parameters for many molecular species (more than one million spectral lines). LBL models are too complex and specialized for discussion here.

Less complex spectral "band" models are simplified LBL models as described in[13]. Band models represent groups of absorption lines as transmittance functions of 
parameters such as absorber concentration, pressure, and absorption coefficients. MODTRAN (Moderate Resolution) and LOWTRAN (Low Resolution) developed by AFGL are popular, commercially available band models. "Low" resolution corresponds to 20 wavenumbers $(0.2 \mathrm{~nm}$ at $300 \mathrm{~nm}$ to $32 \mathrm{~nm}$ at $4000 \mathrm{~nm})$ and "moderate" resolution corresponds to two wavenumbers $(0.02 \mathrm{~nm}$ at $300 \mathrm{~nm}$ to $3 \mathrm{~nm}$ at $4000 \mathrm{~nm})$.

These models can address complex scenarios, including clouds, fog, smoke, many choices of standard and user defined aerosol properties, atmospheric structure for up to 33 different layers, and extraterrestrial spectra. They are designed to compute atmospheric transmittance between two points on or above the earth's surface. The many combinations of input parameters and their interaction require a great deal of understanding by the user. Interpretation of the results is daunting as well.

Simpler spectral models are based on parameterizations of transmittance and absorption functions for basic atmospheric constituents. These usually are molecular, Rayliegh, ozone, water vapor, and aerosol transmittances. An extraterrestrial spectrum is modified by the product of transmittance coefficients or functions and the path length and geometry to produce the transmitted solar spectral distribution. There spectral resolution is generally lower (on the order of nanometers) than that of complex models.

SPCTRAL2, the simple spectral model of Bird[18], SEDES2 (derived from SPCTRAL2)[19] and the Simple Model for Atmospheric Transmission of Sunshine (SMARTS2) of Gueymard[20] represent this approach, after Leckner[21] . SEDES2 is a modified version of SPCTRAL2 where cloud cover and measured broadband global irradiance is used to modify the clear sky SPCTRAL2 model for use under cloudy skies. These models require fewer input parameters. They are useful for engineering applications requiring less accuracy and resolution than complex models. MODTRAN and SMARTS2 have been shown to agree to within better than $2 \%[19]$. Integrated spectral results from both have been used as benchmarks to evaluate the performance of broadband models.

\subsubsection{Direct Beam Broadband Parameterization}

Simple broadband models for clear sky atmospheric transmission of the direct beam are based on the product of broadband extraterrestrial beam radiation and "bulk transmittance" functions. A chapter by Davies in a 1984 IEA report[22] describes these models, of the form $\mathrm{B}=\mathrm{Bo} \mathrm{e}^{\mathrm{-a} / \mathrm{m}}=\mathrm{Bo}^{*} \mathrm{~T}$, where $\mathrm{a}$ is an absorption coefficient, $\mathrm{m}$ the air mass. The exponential term represents a bulk transmittance $(\mathrm{T})$ derived from Rayliegh (Tr), Ozone (To), water (Tw), aerosol (Ta), and mixed gas (Tg) transmittances. A more common form of this approach is to apply the individual transmittances multiplicatively, as in $\mathrm{B}=\mathrm{Bo} * \mathrm{Tr}^{*} \mathrm{Ta}{ }^{*} \mathrm{Tw}^{*} \mathrm{To}{ }^{*} \mathrm{Tg}$. Davies[23] states that the "main uncertainty in computing beam irradiance in either [of these forms] rests in defining appropriate values of Ta".

Gueymard[24] reviewed 22 direct beam transmission models. He compared model results with the SMARTS2 spectral direct beam model results as a reference. For 19 of the models, the MBE in the DNI estimate ranges from $-11 \%$ to $+12 \%$ and the RMSE differences ranged from $3 \%$ to $21 \%$ for mean irradiance of $423.4 \mathrm{~W} / \mathrm{m}^{2}$. For 17 of the models, the MBE was $<10 \%$, and for 13 of the models, the RMSE was less than 
$10 \%$. These represent bias and random errors of less than $45 \mathrm{~W} / \mathrm{m}^{2}$, or about twice the $+/-$ $25 \mathrm{~W} / \mathrm{m}^{2}$ measurement uncertainty for pyrheliometers in table 2 .

Bird and Hulstrom[25] described five models, (Lacis and Hansen[26]; Atwater and Ball[27]; Watt [28]; Hoyt[29]; and Davies and Hay[30]) and a variant of his own (the "Bird" clear sky model mentioned above) that generate direct and hemispherical radiation. Bird reported typical differences among the various model-derived hemispherical radiation and a theoretical model references (BRITE Monte Carlo radiative transfer code[31]) ranging from $7 \%$ to $10 \%$ for total irradiance levels between 1100 $\mathrm{W} / \mathrm{m}^{2}$ and $200 \mathrm{~W} / \mathrm{m}^{2}$. This amounts to differences of $20 \mathrm{~W} / \mathrm{m}^{2}$ to $100 \mathrm{~W} / \mathrm{m}^{2}$, comparable with pyranometer uncertainties of $25 \mathrm{~W} / \mathrm{m}^{2}$ to $100 \mathrm{~W} / \mathrm{m}^{2}$ in table 2 .

\subsubsection{Direct Irradiance from Conversion Models}

A second approach to obtaining direct beam estimates is to convert existing hemispherical data to direct beam irradiance. This is most generally done by developing relationships between clearness indices (ratios of measured to extraterrestrial values of radiation) denoted by $\mathrm{Kt}$, after Liu and Jordan[32]. Sometimes other climatological or meteorological parameters (temperature, humidity, or cloud cover information) are also used to augment the clearness index approach. Empirical correlations of diffuse to global ratios and diffuse to direct radiation can also be used to try and reduce errors in computing hemispherical radiation from estimates of direct and diffuse radiation, especially under non-clear skies. The Perez Anisotropic Diffuse Model[33] is an extensively validated model to convert hemispherical data on a horizontal surface to hemispherical data on tilted surfaces by computing diffuse on the tilted surface.

Perez and Stewart, 1986[34]; Perez et al., 1990[35]; Perez et al., 1992[36] reviewed the performance of global (on a horizontal surface) hemispherical to direct beam conversion models. In Perez et al., 1990[33], MBE of -50 to $+30 \mathrm{~W} / \mathrm{m}^{2}$ and RMSE of $85 \mathrm{~W} / \mathrm{m}^{2}$ to $100 \mathrm{~W} / \mathrm{m}^{2}$ for three different models are shown. The authors state that the Maxwell DISC model performed the best, with the smallest MBE $\left(25 \mathrm{~W} / \mathrm{m}^{2}\right)$ and RMSE $\left(85 \mathrm{~W} / \mathrm{m}^{2}\right)$ under all conditions. In Perez et al., 1992[34] the authors reviewed five models for deriving direct beam from hemispherical data. They evaluated performance against measured data from 18 sites in the U.S. and Europe, again with typical bias errors in the range of $25 \mathrm{~W} / \mathrm{m}^{2}$ and RMSE errors on the order of $80 \mathrm{~W} / \mathrm{m}^{2}-100 \mathrm{~W} / \mathrm{m}^{2}$.

Table 4 summarizes reported model uncertainties surveyed above, as well as more recent work with satellite-based estimates of hemispherical radiation; which have rather larger bias and random components of error, as might be expected. For comparison purposes, the table begins with typical estimated measurement data uncertainties.

\subsection{Conclusion: Models Can Only Be Proven as Good as the Data}

Comparing the highly summarized results above with the measurement uncertainty reported in table 2 , we conclude that at the beginning of the $21^{\text {st }}$ century, current solar radiation models and measurements are rather comparable, with absolute measurement uncertainties on the order of 25 to $100 \mathrm{~W} / \mathrm{m}^{2}$ in hemispherical measured data, and $+/-25 \mathrm{~W} / \mathrm{m}^{2}$ in direct beam measured data. Many models are available for 
estimating direct beam with bias errors of less than $50 \mathrm{~W} / \mathrm{m}^{2}$ and random (model) errors of less than $100 \mathrm{~W} / \mathrm{m}^{2}$.

The challenge for solar radiation misprints and models in the $21^{\text {st }}$ century is to reduce the uncertainty in measured data, as well as develop more robust models (i.e., fewer input parameters and smaller residuals, under a wider variety of conditions). The immediate remedy in the field of measurements is to apply appropriate detailed corrections to measured data, using functions developed from the individual response curves of instruments, as shown in figure 6 and 7. The long-term preference is for more accurate instrumentation with better geometrical and temperature response. In any case, models developed or validated on the basis of existing measured data are limited, at best, to the measurement uncertainties quoted above. 
Table 4. Summary of quoted uncertainties for various broadband solar radiation models reviewed in the literature.

\begin{tabular}{|c|c|c|c|c|}
\hline $\begin{array}{l}\text { Radiation } \\
\text { Component }\end{array}$ & Reference/Model & Bias & Random & Comments \\
\hline All sky Direct & MEASURED DATA & $2 \%$ & $\begin{array}{l}1 \% \text { (about } \\
\text { responsivity } \\
\text { curve) }\end{array}$ & $\begin{array}{l}\text { Single (mean) } \\
\text { responsivity }\end{array}$ \\
\hline $\begin{array}{l}\text { All Sky } \\
\text { Hemispherical }\end{array}$ & MEASURED DATA & $10 \%$ & $\begin{array}{l}1 \% \text { (about } \\
\text { responsivity } \\
\text { curve) }\end{array}$ & $\begin{array}{l}\text { Single } \\
\text { responsivity @ } \\
45^{\circ} \text { reference }\end{array}$ \\
\hline $\begin{array}{l}\text { Direct and } \\
\text { Hemispherical } \\
\text { All sky }\end{array}$ & Maxwell 1998 Metstat[9] & $\begin{array}{c}5.2 \% \text { (Direct) } \\
3.0 \% \\
\text { (Hemispherical) }\end{array}$ & $8 \%-10 \%$ & $\begin{array}{l}\text { Annual Mean } \\
\text { daily total; } \\
33 \text { U.S. } \\
\text { measurement sites }\end{array}$ \\
\hline $\begin{array}{l}\text { Direct and } \\
\text { Hemispherical } \\
\text { All sky }\end{array}$ & Maxwell CSR[10] & $1.0 \%$ & $7.0 \%$ & $\begin{array}{l}\text { Monthly mean } \\
\text { daily total } 8 \\
\text { Egyptian } \\
\text { measurement sites }\end{array}$ \\
\hline Hemispherical & Gueymard/Angstrom[12] & $-2 \%+15 \%$ & & $\begin{array}{l}\text { Annual mean } \\
\text { daily total } 2 \\
\text { models, } 3 \\
\text { Canadian sites }\end{array}$ \\
\hline Direct, Clear Sky & $\begin{array}{l}\text { Gueymard Direct } \\
\text { Transmit (personal } \\
\text { Comm.) }\end{array}$ & $+/-10 \%$ & $+/-10 \%$ & $\begin{array}{l}\text { Mean of } 17 \text { best } \\
\text { out of } 22 \text { models; } \\
\text { reference } \\
\text { SMARTS2 } \\
\text { spectral } \\
\text { integrations }\end{array}$ \\
\hline $\begin{array}{l}\text { Hemispherical, } \\
\text { Clear Sky }\end{array}$ & $\begin{array}{l}\text { Bird \& Hulstrom / } \\
\text { Hemispherical[25] }\end{array}$ & $7 \%-10 \%$ & & $\begin{array}{l}\text { Mean of } 5 \text { models, } \\
\text { Reference BRITE } \\
\text { spectral } \\
\text { integrations }\end{array}$ \\
\hline $\begin{array}{l}\text { Direct from } \\
\text { Hemispherical, } \\
\text { all sky }\end{array}$ & $\begin{array}{l}\text { Perez 1990 } \\
\text { Conversion[35] }\end{array}$ & $5 \%$ & $8.5 \%$ & $\begin{array}{l}\text { Mean of } 3 \mathrm{GH}- \\
>\text { DNI conversions }\end{array}$ \\
\hline $\begin{array}{l}\text { Direct from } \\
\text { Hemispherical, } \\
\text { all sky }\end{array}$ & $\begin{array}{l}\text { Perez } 1992 \\
\text { Conversion[36] }\end{array}$ & $3 \%$ & $8.5 \%$ & $\begin{array}{l}5 \text { models; } 18 \text { US } \\
\& \text { European sites }\end{array}$ \\
\hline $\begin{array}{l}\text { All sky } \\
\text { Hemispherical } \\
\text { from satellite }\end{array}$ & Skartveit, et al. 1998[37] & $2.3 \%$ & $11 \%$ & $\begin{array}{l}5 \text { models ; } 4 \\
\text { European sites }\end{array}$ \\
\hline $\begin{array}{l}\text { All Sky } \\
\text { Hemispherical }\end{array}$ & Gul et al. 1998[38] & $5.0 \%$ & $8.0 \%$ & $\begin{array}{l}3 \text { models, ref } 1000 \\
\text { w/m2; } 12 \text { UK } \\
\text { stations }\end{array}$ \\
\hline $\begin{array}{l}\text { All Sky } \\
\text { Hemispherical } \\
\text { from Satellite }\end{array}$ & Zelenka et al. 1999[39] & $12 \%-15 \%$ & $20 \%$ & $\begin{array}{l}31 \text { Swiss, } 12 \text { US } \\
\text { measurement } \\
\text { stations }\end{array}$ \\
\hline $\begin{array}{l}\text { Hemispherical } \\
\text { on inclined } \\
\text { surfaces } \\
\text { converted to } \\
\text { direct }\end{array}$ & Redmund et al. 1998[40] & $\begin{array}{c}10 \%-20 \% \\
\text { (Hemispherical) }\end{array}$ & & $\begin{array}{l}64 \text { Swiss stations; } \\
\text { stochastic time } \\
\text { series estimation }\end{array}$ \\
\hline
\end{tabular}




\section{References}

[1] Colle S, De Abreu, SL, Ruther R. Uncertainty in economic analysis of solar water heating and photovoltaic systems. Solar Energy, 2001. 70(2): p. 131-142.

[2] WMO. Omm no. 8 guide to meteorological instruments and methods of observation. 5th ed. Omm. Vol. No. 8. 1983, Geneva, Switzerland: Secretariat of the World Meteorological Organization.

[3] WMO. International pyrheliometer comparison viii. Working Report No 1881996 World Meteorological Organization.

[4] ASTM. Astm 913-82 method for calibration of reference pyranometers with axis vertical by the shading method. 1997 American Society for Testing and Materials.

[5] Dutton EG, Michalsky JJ, Stoffel T, Forgan BW, Hickey J, Alberta TL, Reda I. Measurement of broadband diffuse solar irradiance using current commercial instrumentation with a correction for thermal offset errors. Journal of Atmospheric and Oceanic Technology, 2001. 18(3): p. 297-314.

[6] Myers DR, Stoffel TL, Wilcox S, Reda I, Andreas A. Recent progress in reducing the uncertainty in and improving pyranometer calibrations. Journal of Solar Energy Engineering, 2002. 124: p. 44-50.

[7] Wilcox S, bin Mahfoodh M, Al-Abbadi N, Alawaji S, Myers D. Improving global solar radiation measurements using zenith angle dependent calibration factors. in Forum 2001 Solar Energy, The Power to Choose. 2001. Washington D.C: American Solar Energy Society.

[8] Bird R E, Hulstrom R L. A simplified clear sky model for direct and diffuse insolation on horizontal surfaces, seri/tr-642-751. Golden, CO: Solar Energy Research Institute (now National Renewable Energy Laboratory), 1981.

[9] Maxwell EL. Metstat-the solar radiation model used in the production of the national solar radiation data base (nsrdb). Solar Energy, 1998. 62(4): p. 263-279.

[10] Maxwell EL, George RL, Wilcox SM. A climatological solar radiation model. in 1998 Annual Conference- American Solar Energy Society. 1998. Albuquerque, NM: American Solar Energy Society.

[11] NREL. Final technical report national solar radiation data base (1961-1990), nrel/tp 463-5784. Golden, CO: National Renewable Energy Laboratory, 1995.

[12] Gueymard C, Jindra P, Estrada-Cajigal V. A critical look at recent interpretations of the angstrom approach and its future in global solar radiation prediction. Solar Energy, 1995. 54(5): p. 357-363.

[13] IEA. International energy agency validation of models for estimating solar radiation on horizontal surfaces. 1988: Atmospheric Environment Service (Now Environment Canada).

[14] Anderson G P, et al. Modtran2: Suitability for remote sensing. in Atmospheric Propagation and Remote Sensing. 1993: Society of Photo-Optical Instrumentation Engineers.

[15] Anderson GP, et al. History of one family of atmospheric radiative transfer codes. in Passive Infrared remote Sensing of Clouds and the Atmosphere II. 1994: Society of Photo-optical Instrumentation Engineers.

[16] Anderson GP, et al. Reviewing atmospheric radiative transfer modeling: New developments in high and moderate resolution fascode/fase and modtran. in Optical Spectroscopic Techniques and Instrumentation for Atmospheric and Space Research II. 1996: Society of Photo-Optical Instrumentation Engineers.

[17] Rothman LS, et al. The hitran molecular spectroscopic database and hawks (hitran atmospheric workstation): 1996 edition. J. Quant. Spectrosc. Radiat. Trans., 1998. 60: p. 665-710.

[18] Bird RE. A simple, solar spectral model for direct-normal and diffuse horizontal irradiance. Solar Energy, 1984. 32(4): p. 461-471.

[19] Nann S Riordan C. Solar spectral irradiance under clear and cloudy skies: Measurements and a semiempirical model. J. Appl. Meteorol., 1991. 30: p. 447-462.

[20] Gueymard C. Parameterized transmittance model for direct beam and circumsolar spectral irradiance. Solar Energy, 2001. 71(5): p. 325-346.

[21] Leckner B. The spectral distribution of solar radiation at the earth's surface-elements of a model. Solar Energy, 1978. 20: p. 143-150.

[22] IEA. International energy agency handbook of methods of estimating solar radiation. 1984 The Swedish Meteorological and Hydrological Institute. 
[23] Davies J A, Models for estimating incoming solar irradiance, in Handbook of methods for estimating solar radiation. 1984, Swedish Meteorological and Hydrological Institute: Norkopping, Sweden. p. 85106.

[24] Gueymard C. Detailed assessment of accuracies achievable in broadband direct transmittance and irradiance predictions with moderate- and high-performance models. Solar Energy, 2003. (Submitted, Dec 2002).

[25] Bird R E, Hulstrom R L. Direct insolation models, seri/tr-335-344. Golden, CO: Solar Energy Research Institute (now National Renewable Energy Laboratory), 1980.

[26] Lacis A L, Hansen J E. A parameterization of absorption of solar radiation in the earth's atmosphere. Journal of Atmospheric Science, 1974. 31: p. 118-133.

[27] Atwatter M A, Ball JT. A numerical solar radiation model based on standard meteorological observations. Solar Energy, 1978. 21: p. 163-170.

[28] Watt D. On the nature and distribution of solar radiation, hep/t2552-01. Washington, DC: U.S. Department of Energy. 1978.

[29] Hoyt DV. A model for the calculation of solar global radiation. Solar Energy, 1978. 21: p. 27-35.

[30] Davies JA, Hay JE. Calculation of the solar radiation incident on a horizontal surface. in Proceedings, First Canadian Solar Radiation Data Workshop. 1979: Canadian Atmospheric Environment Service (now Environment Canada) Downsview, ON.

[31] Blättner WG, et al. Monte carlo studies of the sky radiation at twilight. Appl. Opt., 1974. 13: p. 534537.

[32] Liu BYH, Jordan RC. The interrelationship and characteristic distribution of direct, diffuse, and total solar radiation. Solar Energy, 1960. 4: p. 1-19.

[33] Perez R, Stewart R, Arbogast R, Seals R, Scott J. An anisotropic hourly diffuse radiation model for sloping surfaces: Description, performance validation, site depenency evaluation. Solar Energy, 1986. 36(6): p. 481-497.

[34] Perez R, Stewart R. Solar irradiance conversion models. Solar Cells, 1986. 18: p. 213-222.

[35] Perez R, Seals R, Zelenka A, Ineichen P. Climatic evaluation of models that predict hourly direct irradiance: Prospects for performance improvements. Solar Energy, 1990. 44(2): p. 99-108.

[36] Perez R, Seals R, Ineichen P, Zelenka A, Maxwell EL. Dynamic global-to-direct irradiance conversion models. ASHRAE Transactions, Research, 1992. 3578(RP-644): p. 354-369.

[37] Skartveit A, Olseth JA, Tuft ME. An hourly diffuse fraction model with correction for variability and surface albedo. Solar Energy, 1998. 63(3): p. 173-183.

[38] Gul MS, Muneer T, Kambezidis HD. Models for obtaining solar radiation data from other meteorological data. Solar Energy, 1998. 64(1-3): p. 99-108.

[39] Zelenka A, Perez R, Seals R, Renne R. Effective accuracy of satellite-derived hourly irradiances. Theoretical Applied Climatology, 1999. 62: p. 199-207.

[40] Redmund J, Salvisberg E, Kunz S. On the generation of hourly shortwave radiation on tilted surfaces. Solar Energy, 1998. 62(5): p. 331-344. 


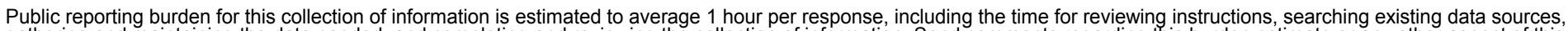

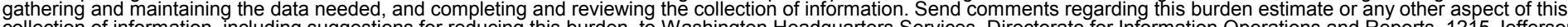

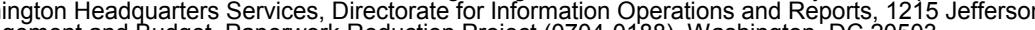
Davis Highway, Suite 1204, Arlington, VA 22202-4302, and to the Office of Management and Budget, Paperwork Reduction Project (0704-0188), Washington, DC 20503.
1. AGENCY USE ONLY (Leave blank)
2. REPORT DATE
March 2003
3. REPORT TYPE AND DATES COVERED
Conference Paper Preprint

4. TITLE AND SUBTITLE

Solar Radiation Modeling and Measurements for Renewable Energy Applications: Data and Model Quality; Preprint

5. FUNDING NUMBERS

PVP3.7401

6. $\operatorname{AUTHOR}(\mathrm{S})$
D.R. Myers

7. PERFORMING ORGANIZATION NAME(S) AND ADDRESS(ES)

National Renewable Energy Laboratory

1617 Cole Blvd.

Golden, CO 80401

8. PERFORMING ORGANIZATION REPORT NUMBER

NREL/CP-560-33620

9. SPONSORING/MONITORING AGENCY NAME(S) AND ADDRESS(ES)

10. SPONSORING/MONITORING AGENCY REPORT NUMBER

11. SUPPLEMENTARY NOTES

12a. DISTRIBUTION/AVAILABILITY STATEMENT

National Technical Information Service

12b. DISTRIBUTION CODE

U.S. Department of Commerce

5285 Port Royal Road

Springfield, VA 22161

13. ABSTRACT (Maximum 200 words) Measurement and modeling of broadband and spectral terrestrial solar radiation is important for the evaluation and deployment of solar renewable energy systems. We discuss recent developments in the calibration of broadband solar radiometric instrumentation and improving broadband solar radiation measurement accuracy. An improved diffuse sky reference and radiometer calibration and characterization software and for outdoor pyranometer calibrations is outlined. Several broadband solar radiation model approaches, including some developed at the National Renewable Energy Laboratory, for estimating direct beam, total hemispherical and diffuse sky radiation are briefly reviewed. The latter include the Bird clear sky model for global, direct beam, and diffuse terrestrial solar radiation; the Direct Insolation Simulation Code (DISC) for estimating direct beam radiation from global measurements; and the METSTAT (Meteorological and Statistical) and Climatological Solar Radiation (CSR) models that estimate solar radiation from meteorological data. We conclude that currently the best model uncertainties are representative of the uncertainty in measured data.

14. SUBJECT TERMS Modeling; broadband; spectral terrestrial solar radiation; calibration; solar radiometric instrumentation

15. NUMBER OF PAGES

17. SECURITY CLASSIFICATION OF REPORT Unclassified

NSN 7540-01-280-5500
19. SECURITY CLASSIFICATION OF ABSTRACT Unclassified

Unclassified

16. PRICE CODE

20. LIMITATION OF ABSTRACT

UL

SECURITY CLASSIFICATION
OF THIS PAGE
Unclassified

Standard Form 298 (Rev. 2-89) Prescribed by ANSI Std. Z39-18 